\title{
Historiese agtergrond en ontwikkeling van die Proponentsondertekeningsformule in die Reformatoriese tradisie
}

\author{
S J Botha \\ Departement Kerkgeskiedenis \\ Universiteit van Pretoria
}

\begin{abstract}
Historical background and development of the formula which must be signed by candidate ministers in the Reformed tradition

The origin and the development of the tradition in the Reformed churches of binding all candidates for the ministry to the confession of faith as it is expressed in both the ecumenical and reformed confessions, by expecting them to sign a specific formula, and how this tradition was kept up in the Nederduitsch Hervormde Church, is researched.
\end{abstract}

\section{INLEIDING}

Die tradisie in die Reformatoriese kerke om die kandidate vir die amp van dienaar van die Woord aan die belydenis, soos verwoord in die drie ekumeniese belydenisse asook in Reformatoriese belydenisskrifte, deur 'n bepaalde formule te bind, gaan terug tot in die sestiende eeu. Trouens, relatief kort na die aanvang van die Reformasie, is reeds van die kandidate verwag om die Reformatoriese belydenisskrifte te onderteken, aanvanklik sonder enige bepaalde formule. Die oogmerk van hierdie artikel is om die ontstaan van die tradisie en die neerslag daarvan in die Nederduitsch Hervormde Kerk, kortliks na te gaan. 


\section{DIE KERKHERVORMING EN BELYDENISSE}

Ten spyte daarvan dat die Reformatore en veral Calvyn, voortdurend daarteen gemaan het dat nie ligtelik nuwe belydenisse opgestel moet word nie (Plomp 1969:246), het die Kerkhervorming tog ' $n$ aanmerklike uitbreiding van. die belydenisskat van die kerk gebring. Die Reformatore wou teenoor al die vreemde dinge wat in die kerk ingesluip het, alleen die evangelie, die Woord van God stel (Augustyn 1971:6). Daarom was daar by hulle ' $n$ sterk houding van terughoudendheid wanneer die vraag na die opstel van 'n geloofsbelydenis ter sprake was. Die opstel van belydenisse is wel nie prinsipieel afgewys nie, maar daar is gewaarsku teen menslike onbestendigheid en daarom moes 'n belydenis so kort moontlik met woorde uit die Bybel opgestel word. 'n Argument wat aangevoer is, was dat indien die Woord van God mense nie kon raak nie, hoe sou mensewoorde dit kon doen (Augustyn 1971:7)? Onder die nood van bepaalde omstandighede is ook die Reformatore en Reformatoriese kerke egter gedwing tot eksistensiële beslissings om hulle geloof daadwerklik te bely (De Wet 1973:41).

By die aanvaarding van belydenisskrifte waarin die belydenis vervat is, het die vraag na die gesag van sulke belydenisskrifte vanselfsprekend na vore gekom. By herhaling is dit beklemtoon dat die belydenisskrifte mensewerk was en nou het die vraag ontstaan: kan en mag mensewerk gesag hê en sal dit nie afbreek doen aan die gesag van die Skrif nie? Watter sin het dit hoegenaamd om 'n geloofsbelydenis te hê? Matig die kerk hom nie hierin aan om Gods Woord te wil aanvul of dalk selfs te vervang nie? (Augustyn 1971:8). Dit was almal gewigtige vrae waarmee die Reformatoriese kerke moes worstel. In die worsteling rondom hierdie en verwante vrae, het die posisie van die belydenisskrifte in die Calvinistiese kerke, veral in Nederland ' $n$ bepaalde ontwikkeling deurgemaak. Augustyn se konklusie in die verband kan soos volg opgesom word (Pont 1982:20):

- Oorspronklik is die belydenisskrif die verklaring van geloof, 'n verklaring van hoe die Heilige Skrif op bepaalde punte verstaan word. Op daardie stadium is die belydenisskrif vir die eie kring bedoel.

- Dan word die belydenisskrif vollediger en meer teologies van aard. So word die belydenisskrif ' $n$ saambindende getuienis wat terselfdertyd ook gerig is op die medegelowiges en die buitestanders. 
- Ten slotte word die belydenisskrif ' $n$ middel om die kerk te beskerm teen kettery binne die kerk self. Dan word dit die duidelike omskrywing van die grense van die kerk. So word die belydenisskrif ook as norm en reël van die prediking, die kort saamgevatte regula fidei.

Waar die nood van die omstandighede die Reformatoriese kerk gedwing het tot die opstel van belydenisskrifte, het die nood van omstandighede die kerk ook gedwing om die belydenisskrifte as beskermmiddele teen kettery te gebruik. Pont noem dit die nood wat deur die sonde van die mens veroorsaak is (Pont 1982:21). Die ondertekening van die belydenisskrifte, wat reeds van vroeg af in die Reformatoriese kerke tradisie geword het, en dus die binding aan die belydenisskrifte, het nou ook hierdie betekenis bygekry. Die ondertekening van die belydenisskrifte, sonder nadere bepaling, het egter gou geblyk nie genoeg te wees nie. Binne hierdie situasie het die verskillende formules ontstaan waarin presies bepaal is hoe die belydenisskrifte onderteken moes word.

\section{CALVYN EN BINDING AAN DIE BELYDENISSKIFTE}

Voordat verder na die ontstaan van enkele ondertekeningsformules gekyk word, is 'n paar opmerkings oor Calvyn se beskouing ten opsigte van die saak tog van belang. Enersyds kan daar geen twyfel wees daaroor dat Calvyn binding aan die belydenis, en dan ook aan 'n "bepaalde, skriftelike vorm van die leer", vir sowel lidmate as predikante noodsaaklik geag het nie. Andersyds is dit tog ook so dat hy by geleentheid geweier het om die drie ekumeniese simbole te onderteken. Dit mag merkwaardig en selfs inkonsekwent voorkom, maar daaruit blyk tog hoedat Calvyn oor ondertekening van en binding aan die belydenisskrifte gedink het.

Teen die einde van Augustus 1536 het Calvyn met sy dienswerk in die Petruskerk in Genève begin, aanvanklik deur slegs Bybellesings oor die briewe van Paulus te hou. Dit was inderdaad ' $n$ onopvallende werk en hy het heeltemaal in die skadu van die baanbreker van die hervorming in Genève, Gillaume Farel, beweeg. Na 'n godsdiensgesprek te Lausanne met Rooms-Katolieke teoloè, waarin Calvyn hom onderskei het, het die inwoners van Genève eers werklik kennis geneem van hom. Eers teen die einde van 1536 is Calvyn deur die Geneefse stadsraad as predikant aangestel en kon hy met meer 
gesag aan die ordening van die hervorming van die kerk in Genève meedoen. Een van die eerste take wat hy ter hand geneem het, was om ter wille van die organisasie van die kerk van Genève 'n aantal geloofsartikels op te stel (Parker 1975:62; vgl Dankbaar 1957:47). Kort nadat die stadsraad van Genève die artikels op 16 Januarie 1537 aanvaar het, het ook van die hand van Calvyn 'n kategismus gevolg, en daaruit het hy weer 'n uittreksel gemaak wat as die Geloofsbelydenis van Genève bekend geword het (Augustyn 1971:29; Parker 1975:62). Na sterk aandrang van Calvyn en Farel het die lede van die stadsraad met 'n eed beloof om die Geloofsbelydenis te bewaar en te hou. Daarna moes ook die burgers van die stad openlik in die kerk dieselfde eed gaan aflê. Diegene wat nie daartoe bereid was nie, het hulle burgerskap verloor en kon en is ook gewoonlik daarna uit die stad verban (Dankbaar 1957:49). Nie al die inwoners van Genève was tot hierdie prosedure bereid nie en dit het, saam met ander redes, daartoe gelei dat Farel en Calvyn self vroeg in 1538 uit Genève verban is.

Terwyl Calvyn so sterk oor die binding van al die lidmate (= inwoners van Genève) aan die Geneefse Geloofsbelydenis gevoel het, het hy nog in dieselfde jaar egter self geweier om die drie ekumeniese geloofsbelydenisse te onderteken. Dit het gebeur toe Pierre Caroli, predikant te Lausanne, Calvyn en Farel van Arianisme beskuldig het. Om die beskuldiging te ondersoek, het 'n sinode te Bern vergader en daar het Caroli sy beskuldiging herhaal en aanspraak daarop gemaak dat Calvyn en Farel 'n afwykende leer oor die Triniteit daarop nagehou het. Hy het hulle daarom gedaag om die drie belydenisse te onderteken. Calvyn het summier geweier en vir die weiering het hy drie redes aangevoer (Hesselink 1997:110):

- Hy het verklaar dat hy reeds elders baie duidelik sy geloof in die Drie-enige God bevestig het. Sy Geneefse Kategismus en Geloofsbelydenis, wat pas tevore verskyn het, was daarvan 'n duidelike bewys.

- Hy het daarop aangedring dat Caroli nie die reg gehad het om so 'n eis te stel nie.

Dit was nie alleen aanmatigend nie, maar daarmee sou 'n voorbeeld van tirannie in die kerk ingevoer word, “... zodat iemand die niet zou hebben gesproken naar het voorbeeld van een ander, voor een ketter zou worden gehouden" (Dankbaar 1957:51). 
Hy het ook daarop gewys dat die Geloofsbelydenis genoem na Athanasius, nooit amptelik deur ' $n$ groot konsilie aanvaar is nie.

Dit wil voorkom of Calvyn sy standpunt ten opsigte van die lidmate se aanvaarding van die Geloofsbelydenis met 'n eed, later ietwat gewysig het. Augustyn toon aan dat Calvyn na sy terugkeer na Genève in 1541, nie weer probeer het om die burgers met ' $n$ eed binding aan die Geloofsbelydenis te laat beloof nie, ten spyte daarvan dat hy 'n nuwe Kategismus opgestel het wat inderdaad ook as 'n geloofsbelydenis gegeld het (Augustyn 1971:30). Daar kan meer as een oorsaak wees waarom Calvyn sy standpunt ietwat gewysig het. Een moontlikheid is dat die aanvanklike bedoeling wat hy en Farel met hulle optrede beoog het, naamlik om die inwoners van Genève tot 'n persoonlike keuse te bring, teen daardie tyd nie meer werklik nodig was nie. Bowendien het die plegtige aflegging van belydenis van geloof deur die jong lidmate hierdie funksie opgevang. Van die predikant het Calvyn egter steeds ' $n$ belofte om hom aan die kerklike belydenis te hou, vereis. So het die Ordonnances Ecclesiastique van 1541, wat deur Calvyn by sy terugkeer na Genève opgestel is, in artikel 7 bepaal (Pont 1981:23): "Om elke gevaar te vermy dat die kandidaat een of ander dwaalleer aanhang, sal van hom 'n belofte geëis word dat hy hom aan die leer, wat die kerk goedgekeur het, sal hou. Hier sal die inhoud van die Kategismus normatief wees."

Hoewel aanvanklik nie bepaal is dat die Kategismus normatief sou wees nie (Augustyn 1971:33), is dit egter betekenisvol dat die bepaling tog baie gou bygevoeg is. Calvyn het dus blykbaar vroeg reeds besef dat ook duidelik gestel moes word waar die leer van die kerk verwoord is en die kerklik aanvaarde Kategismus, wat ook van sy hand was, het na sy oortuiging hieraan voldoen. Terloops kan daarop gewys word dat Calvyn van mening was dat al die verskillende Reformatoriese kerke én kategismus behoort te gehad het. Tog was hy realisties genoeg om te erken dat daar verskeie redes bestaan waarom elke kerk sy eie kategismus sou hê (Augustyn 1971:30).

Dit is ook van belang om daarop te let hoe artikels 6 en 8 van die Ordonnnances Ecclesiastique, wat die omraming vir artikel 7 bied lui:

Die eksamen bestaan uit twee dele. Die eerste staan in verband met die leer, naamlik of die beroepene 'n goeie en deeglike kennis van die Skrif het, en 
verder, of hy geskik en bekwaam is om die Skrif tot opbouing van die gemeente te verkondig.

Om vas te stel of hy bekwaam is om te leer, sal daar vrae aan hom gestel word en sal, in geslote kring, geluister word hoe hy die leer van die Here uiteensit.

(Pont 1981:23)

Voordat 'n kandidaat tot evangeliebediening toegelaat en beroepbaar gestel is, moes dus eers vasgestel word of hy die leer van die kerk begryp het en of hy dit sou kon uitlê. Dit spreek seker vanself dat indien die kandidaat by die genoemde ondervraging enige onsekerheid ten opsigte van die leer van die kerk sou openbaar, hy nie toegelaat sou word nie. In so 'n geval sou die Kategismus seker ook as norm gegeld het. Bowendien moes die predikant ook nog die volgende formule onderteken:

Ek beloof om getrou die Woord van God te verkondig tot stigting van die
volk, en met 'n goeie gewete die kerk waaraan God my verbind het, te dien;
om gehoorsaam te wees aan die owerheid, én eiendom én eer te beskerm soos
'n ware gelowige dit behoort te doen; en 'n goeie voorbeeld van onder-
danigheid te stel, deur die wette en bevele van die genoemde owerheid te
gehoorsaam, altyd met behoud van die vryheid om die Woord van God te
verkondig soos ons plig volgens sy Heilige opdrag dit vereis.

(Eie vertaling uit die Nederlands, soos aangehaal by Goddefroy 1890:21)

In hierdie formule word wel nie verwys na die leer of belydenisskrifte van die kerk en watter rol die belydenisskrifte by die ondertekening speel nie. Tog veronderstel die verwysing na "'n goeie gewete" sekerlik dat die ondertekenaar die leer, belydenis en belydenisskrifte van die bepaalde kerk van harte omhels het en hom daarom daaraan sal hou. Dit is trouens seker wat by die eksamen of ondersoek, wat in artikels 6 en 8 ter sprake is, vasgestel moes word.

Calvyn het ook ander kerke opgeroep om sulke ondernemings van hulle predikante te vereis. So het hy in 1548 Eduard Seymore, die hertog van Somerset, in verband met hervorming van die Engelse kerk onder andere soos volg geadviseer: 
Tog dink ek dat dit goed en selfs noodsaaklik is om die predikante te verplig om ' $n$ bepaalde skriftelike vorm van die leer te aanvaar sowel om die gebrek aan kennis en eenvormigheid by sommige te hulp te kom as om ook die ooreenstemming en eenheid van alle kerke beter tot uitdrukking te bring, en in die derde plek om alle nuwighede en nuuskierigheid van predikante, wat alleen maar iets besonders na vore wil bring, in die kiem te smoor. Soos reeds gesê, vir derglike mense moet die kategismus as teuel dien.

(Vertaling van Pont 1982:12)

In dieselfde verband het Calvyn verder verklaar dat niemand tot enige kerklike amp toegelaat behoort te word, wat nie met ' $n$ eed beloof het om hom aan die leer soos in 'n aanvaarde kategismus vervat is, te hou nie (Augustyn 1971:34). Om 'n belofte met 'n eed te bekragtig het seker net soveel regsgeldigheid as om dit met 'n handtekening te beseël. In beginsel was Calvyn dus duidelik ten gunste daarvan dat kandidate vir predikantsamp (en ook vir die ander ampte) een of ander openlike onderneming moes gee om hom by die goedgekeurde leer van die kerk te hou.

Dit was daarom te wagte dat oral waar die Calvinistiese hervorming ingevoer is, bepalings met dié strekking gemaak sou word. Een van die eerste voorbeelde was die Franse Hervormde kerk. Teen 1555 het daar al in Frankryk 'n min of meer georganiseerde hervormde kerk in Frankryk begin verskyn, hoofsaaklik in Parys, maar ook elders. Daar kan geen twyfel bestaan daaroor dat die Franse Hervormde Kerk opgebou is deur die strategie van Calvyn nie. Feitlik al die predikante wat daar gewerk het, was leerlinge van Calvyn (Augustyn 1971:35; Pont 1981:48). 'n Waagmoedige stap is in 1559 geneem, as in Mei 'n sinodale vergadering van al die gemeentes in die grootste geheimhouding te Parys byeenkom. Die bedoeling was om die verskillende Franse gemeentes in een landelike kerk te organiseer. Met die $00 \mathrm{~g}$ daarop is beplan om een geloofsbelydenis en een kerkorde daar te stel. Van Calvyn is advies gevra en hy het aan die sinode advies gegee. Hoewel hy nie besonder ingenome was met die idee om nog 'n verdere geloofsbelydenis op te stel nie en verklaar het dat die Kategismus van Genève ook vir die Franse kerk bruikbaar was, het hy tog 'n konsep gestuur. Hierdie konsep is met enkele wysigings deur die sinode aanvaar. Interessant egter was dat die sinode nog voordat 'n eie geloofsbelydenis aanvaar is, reeds 'n gemeenskaplike kerkorde bekragtig 
het. Vir die kerkorde het die Geneefse Ordonnances Ecclesiastique as model gedien en op voetspoor van Calvyn is in die Franse Discipline Ecclesiastique in artikel 8 bepaal: "Dat diegene wat beroep word die belydenis van geloof sal onderteken, wat bepaal is sowel by die kerk waar hulle beroep is as ander, waarheen hulle gestuur sal word ..." (Pont 1981:51).

Dit beteken dus dat van alle predikante ondertekening van 'n geloofsbelydenis vereis is nog voordat 'n gemeenskaplike geloofsbelydenis aanvaar is (Augustyn 1971:36). Hier was wel nie sprake van 'n formule wat bepaal het hoe die geloofsbelydenis onderteken word nie. Op daardie stadium was die primêre oogmerk van hierdie bepaling nog die betuiging van eenheid in die geloof (Augustyn 1971:35).

\section{DIE PROPONENTSONDERTEKENINGSFORMULE IN DIE NEDERLANDSE HERVORMDE KERK}

Die Calvinistiese Hervorming het Nederland vanuit Frankryk via die hoofsaaklik Franssprekende suidelike Nederlande binnegekom. Aanvanklik was die meerderheid van die gemeentes wat tot stand gekom het Franssprekend, hoewel ook Nederlandssprekende gemeentes gevorm is. Die Calvinisme was nie aanvanklik die sterkste onder die nieRooms-Katolieke groeperinge in Nederland nie. Trouens dit het eers relatief laat in Nederland begin posvat maar het daarna redelik vinnig gegroei. Ouer nie-Rooms-Katolieke groepe was verdeel onder die Lutherane, die sakramentariërs en die Ana-baptiste (Pont 1994:19-34). Die Calvinisme het egter 'n besondere lewenskragtigheid geopenbaar en het ten spyte van die bloedige vervolgings deur Keiser Karel $\mathrm{V}$ en daarna sy seun Philips II van Spanje, tog dermate gegroei dat hulle spoedig die sterkste enkele groep geword het.

Oral, aanvanklik hoofsaaklik in die Franssprekende suide, is gemeentes gevorm en kerkrade gekies. Vanuit die kerkraadsvergaderings is daar weer provinsiale sinodes saamgestel waarvan die werksaamhede tussen 1563; 1566 deur middel van behoue acta bekend is (Pont 1981:55; 1994:53ev). Onder die kerkordelike reëlings deur die Waalse sinodes onder die kruis, soos hulle bekend gestaan het, is daar duidelik bepaal dat sowel die predikante as die ouderlinge en die diakens die aanvaarde geloofsbelydenis moes onderteken (Pont 1994:53). Die geloofsbelydenis waarvan hier sprake is, is die Confessio 
Belgica wat in 1561 deur Guido de Brès opgestel en in 1563 by 'n provinsiale sinode van Armentiéres as belydénisskrif van die kerk aanvaar is (Pont 1994:53). Die invloed van die Confessio Gallicana en die Discipline Ecclesiastique van 1559 van die Franse hervormde kerk was hier bepalend. Ook verdere maatreëls ten opsigte van die predikant en die belydenis is getref soos onder andere:

Diegene wat maar kort gelede tot die kerk toegelaat is, veral monnike en priesters, kan nie tot die diens (van die Woord) gekies word sonder 'n lang en noukeurige ondervraging én goedkeuring van sowel hulle leer as lewe nie. Tug moes toegepas word op: Dienaars (van die Woord) wat 'n verkeerde leer verkondig en nie daarmee ophon nadat hulle voldoende vermaan is nie; Dienaars (van die Woord) of ander persone in die kerk kan nie enige boeke laat druk of publiseer nie, maar dit moet (vir goedkeuring) aan drie dienaars van die Woord, wat bo verdenking staan, voorgelê word.

Wanneer die predikante die geleentheid het om dikwels saam te vergader om oor die Christelike leerstellings te handel, so ook in die sinode wat om hierdie rede dikwels byeenkom, sal die predikant wat dit bywoon om die beurt, elke oggend en na ete, 'n Skrifgedeclte behandel, om sodoende te getuig van die eenheid van die leer wat daar onder hulle bestaan.

(Pont 1981:58-59)

Hoewel daar nie ' $n$ bepaalde formule gestel is waarin noukeurig bepaal is hoe die ampsdraers die belydenisskrifte moet onderteken nie, kan tog uit die enkele bepalings wat hier genoem word, afgelei word dat, terwyl die primêre funksie daarvan was om 'n verklaring van geloof en 'n betuiging van eenheid in die leer uit te druk, die belydenisskrif reeds toe al die funksie begin vervul het om 'n middel te wees om die kerk teen kettery binne die kerk self te beskerm. Daarom die bepalings dat, voordat iemand as predikant toegelaat word, vasgestel moes word of hy in die leer suiwer was. Hoe anders sou dit bepaal kon word as om dit te meet aan die aanvaarde en goedgekeurde belydenisskrif? Hoe anders is bepaal watter dienaars van die Woord bo verdenking gestaan het as die belydenisskrif nie 6ók as maatstaf gegeld het nie? Op die wyse was die beginsel reeds 
teenwoordig waaruit 'n noukeurige formule wat bepaal het hoe die belydenisskrifte onderteken word, ontwikkel sou word.

Die gebruik om die belydenisskrifte te onderteken, soos dit in die Suid-Nederlandse gemeentes ontstaan het, is aanvanklik tot 1571 nie in die Noord-Nederlandse gemeentes nagevolg nie. By die convent van Wesel is daar wel die vereiste gestel dat by 'n beroepe predikant navraag gedoen sal word "... of hij niet enige ketterij toegedaan is geweest; of hij niet in vreemde en curieuse vragen, en ledige speculatiën meer als billik is, zich heeft vermaakt; of hij niet naarstiger als het betaamt ketterse boeken heeft gelezen ..." (Pont 1981:72). Van hom is verder vereis dat hy moes instem met die leer soos dit vervat was in die Franse en Nederlandse Geloofsbelydenisse. Van ondertekening van die belydenisskrifte was daar op daardie stadium geen sprake nie (Pont 1994:81). By die Sinode van Emden 1571 word die gebruik om die belydenisskrifte te onderteken vir die hele Nederlandse kerk aanvaar as in artikel 2 van die Kerkorde bepaal word:

Om de eendrachtigheid in de leer tussen de Nederlandse kerken te bewijzen, heeft het de broederen goed gedacht de belijdenis des geloofs der Nederlandse kerken te onderschrijven; insgelijks ook de belijdenis der kerken in Frankrijk te ondertekenen, om daarmede haar verbinding en enigheid met dezelve Franse kerken te betuigen, zekerlijk vertrouwende, dat de dienaren derzelver Franse kerken ook op hun zijde de belijdenis des geloofs der Nederlandse kerken, tot getuigenis der onderlinge eendrachtigheid, onderschrijven zullen.

(Pont 1981:103)

Spoedig het die provinsiale sinodes van Noord- en Suid-Holland rapporteer dat hulle toegesien het dat al die kerkdienaars die belydenis onderteken het en dat die saak van ondertekening almal se volle steun geniet het. Die klassis Walcheren het selfs verder gegaan en die volgende formulier ontwerp en deur die predikante laat onderteken:

Wij hier ondergeschreven Dienaren des Woorts Godes, binnen desen eylande van Walcheren, gelooven en bekennen mits dezen, dat die voorschreven belijdinghe des geloofs der Christelijke Ghemeenten der Nederlanden, gheleegen onder Co Mat van Spaenyen, begrepen in 37 Artikelen, ghedrukt 
anderwerf in 't Jaer LXXII tot Dordrecht, den woorde Gods in allen stukken gelijkformig is. Ende beloven derhalve onse leere en kerkedienst daernaer te richten, met leeren, vertroosten, en vermanen. En wat daarmede strijdich is naer onsen vermoghen te wederstaen.

(Bouwman 1934, II:567-568)

Waarskynlik is hierdie formule die beginpunt van die tradisie in die Nederlandse kerk om die belydenisskrifte deur 'n naderbepalende formule te onderteken. Al die elemente wat in die opvolgende formules teruggevind word, naamlik die erkenning dat die belydenisse "gelijkformig" aan die Woord van God was, dat dit sal geld as maatstaf van die predikant se dienswerk en sal dien om kettery te weerstaan, was reeds in hierdie formule teenwoordig. Die gebruik om die belydenisskrifte te onderteken is sonder teenstand aanvaar en het redelik gou algemeen geword. Aanvanklik is nie 'n absolute verpligting met 'n gepaardgaande tugmatreël by die ondertekening gestel nie. Tog was dit die verwagting dat alle predikante, ouderlinge, diakens en selfs onderwysers dit sou doen en mettertyd is dit ook verpligtend gestel. Die tradisie om dit deur ' $n$ bepaalde formule te doen sou egter later eers verpligtend word en was die gevolg van die groot leerstryd wat in die Nederlandse kerk ontbrand het oor die twee hoofsake naamlik “... de bepaling der verhouding van de kerk tot de staat en de bepaling van het gezag der belijdenisschriften, derhalve over kerkorde en confessie" (Reitsma en Lindeboom 1949:140).

Op sowel provinsiale as nasionale sinodes wat na die sinode van Emden gevolg het, is die besluit van Emden oor ondertekening van die belydenisskrifte oorgeneem. By die provinsiale sinode van Holland en Zeeland te Dordrecht 1574, die eerste sinodale vergadering op Nederlandse bodem, is bepaal dat ook die kerkorde, as teken van instemming daarmee, onderteken moes word (Pont 1981:115). Ook op die nasionale sinodes van Dordrecht (1578) en Middelburg (1581) is soortgelyke besluite geneem (Augustyn 1971:60). Teen 1583 is by die sinode van Amsterdam rapporteer dat daar nie meer 'n gemeente was waar enige besware teen ondertekening van die belydenisskrifte geopper is nie en was dit dus 'n algemeen aanvaarde gebruik (Bouwman 1934:569). Wat wel nie algemeen was nie, was dat daar slegs een bepaalde formule vir ondertekening gebruik is. Waar 'n verbintenisformule wel gebruik is, is in elke klassis 'n eie een opgestel. In die 
Belydenisboek van die klassis Enkhuizen, wat in 1589 aangelê is, word die volgende formule gevind: "Wij ondergeschreven dienaren des woordts Gods in den classe van Enkhuizen bekennen dese belijdenisse des geloofs in de Bijbelse Schriftuere gegrond te sijn, ende beloven in die kercke Christi niet te leeren dat hier tegen is strijdende, ' $t$ welcke wij met onse handen ende namen bevestigen" (Bouwman 1934:569).

Hierdie ondertekening is alleen verwag van die ampsdraers en nie van die lidmate nie. Van lidmate wat van dwaalleer aangekla is, is daarna verwag om deur ondertekening van die formule hulle van die klag te suiwer.

Hoewel die konvent van Wesel die wens uitgespreek het dat beide die Nederlandse Geloofsbelydenis en die Heidelbergse Kategismus onderteken moes word, het die vroegste ondertekeningsformules nie die Kategismus vermeld nie. Die oudste bekende formule wat beide die Nederlandse Geloofsbelydenis en die Heidelbergse Kategismus ingesluit het, was die volgende formule van die klassis Alkmaar wat op 21 September 1608 vasgestel is:

Wij ondergeschreven Predikanten, behoorende onder den classe van Alckmaer, verclaeren ende betuygen, dat de Leere dewelcke in desen Catechismo, die bij de Geref eendrachtelijk is aengenomen, ende in 37 artijckelen der Nederlantsche Gereformeerde Kercken begrepen, in alles overeenkomt met het Heylige woort Godts, ende dienvolgende met het fundament der Leere der salicheyt. Beloven derhalven de selve Leere, door Godts genade te onderhouden; alle leeringhen, die daer teghen worden voortghebracht, ende daarom daer teghen strijden, opentlijck te verwerpen, ende met alle vlijt ende getrouwicheyt, na vermogen teghen te staen, gelijck wij het selve met onse Hantschriften bevestigen.

(Bouwman 1934:570)

Hierdie ondertekeningsformule het die moederformule van al die opvolgende formules geword. In 1610 het die klassis Buren 'n formule opgestel wat dieselfde verklaring en belofte omvat het, terwyl bowendien ook nog van die predikant antwoord op die volgende drie vrae vereis is: 
1 Of ' $t$ gene sy geantwoort hadden op de voorgestelde Vragen in ' $t$ examen by hem geantwoort was in goede conscientie, sonder dobbelheyt of schalkheyt. 2 Soo sy in eenige stucken begonsten te twyfelen, of anders te gevoelen, dat sy sullen ghelooven ' $t$ selve niet uit te dreyden, nog by hem te houden, maer datelick met de Classe te communiceren, die sal soecken te voldoen.

3 Of de Classen hem in syn goetduncken niet en konde voldoen, dat hy sich sal houden gesuspendeert van den kerckendienst, ter tijdt toe dat de swarigheden ende geschillen, die in de kerken geresen zijn, geslecht sullen wesen.

(Bouwman 1934:571)

Die nuwe element wat hier na vore gekom het, was dat by latere twyfel oor 'n bepaalde leerstuk, dit nie openbaar gemaak sou word nie maar wel onmiddellik aan die klassis bekend gemaak moes word vir beslissing. Nog in dieselfde jaar het die sinode van Zeeland 'n ondertekeningsformule aanvaar waarin die eis opgeneem is dat predikante te enige tyd bereid moes wees om op versoek van die klassis hulle "gevoelen" in verband met enige stuk van die leer nader te verklaar:

... Ende indien tot eenigen tyde de classis ofte synodus zoude mogen goetvinden, om de eenicheyt in de leere te onderhouden, van ons te eysschen onse naedere verclaringhe ofte gevoelen over eenich artickel van de voorsz. Confessie ofte Catechismus, soo belooven wy oock mitsdesen, dat wy daartoe ' $t$ allen tyden zullen bereyt ende willich syn sonder eenige weygeringhe, op pene als boven. ...

(Bouwman 1934:571)

Ook die provinsie Gelderland het in 1612 soortgelyke vereistes in 'n ondertekeningsformule vasgestel. Hierdie ontwikkelinge was die gevolg van die onrus wat in die Nederlandse kerk veroorsaak is deur die optrede van die Arminiaanse Remonstrante. Die belydenisskrifte het nou ontwikkel as middel om die kerk teen kettery in sy eie geledere te beskerm. Die reg tot ondersoek na die leer van die predikante is dus duidelik vasgelê. 'n Verdere logiese ontwikkeling was dat 'n soortgelyke en gelykluidende 
formule opgestel sou word wat 'n proponent by toelating tot die evangeliebediening sou moes onderteken. Die eerste sodanige formule is deur die sinode van Veere daargestel (Bouwman 1934:572).

Toe die groot sinode van Dordrecht in 1618 byeengekom het om die onverkwiklike leerstryd te besleg, was die tradisie om die belydenisskrifte aan die hand van 'n bepaalde en bindende formule te onderteken, reeds redelik algemeen in die Nederlandse kerk gevestig. Die gevolg was dat die opstel en aanvaarding van 'n enkele ondertekeningsformule vir die hele kerk, byna slegs ' $n$ formaliteit op die sinode was. So is die besluit van die sinode in sy 162 e sitting op 16 Mei 1619 “... dat ontworpen worde een accuraet formulier van onderteeckeninghe der Confessie, Catechismo ende synodale verclaringhe waarmede alle Kerckendienaren hun overeenstemminge in de rechtgevoelende leere claerlicke betuygen" (Bouwman 1934:573), wat aan 'n kommissie van vier man opgedra is, onmiddellik uitgevoer en slegs een dag later is ' $n$ formule voor die sinode gelê en na weinig bespreking en geringe verandering eenparig goedgekeur. Die formule het gelui:

Wy ondergeschreve dienaren des Godtlycken Woorts, resorteerende onder de Classe van $\mathrm{N} \mathrm{N}$, verclaeren oprechtelick in goeder conscienti voor den Heere met dese onse onderteeckeninge, dat wij van herten ghevoelen ende gelooven, dat alle de articulen ende stucken der leere in dese Confessie ende Catechismo der gereformeerde Nederllantsche kercken begrepen midtsgaders de verclaeringe over eenige poincten der voorss leere in den Nationalen Sijnode ao 1619 tot Dordrecht ghestelt, in alles met Godts woort over een comen. Beloven derhalve dat wij de voorss leere neerstelick zullen leeren, ende getrouwelyck voorstaen, sonder yet teghen deselve, t' sij opentlick, ofte nit' bysonder, $t$ ' sij directelick ofte indirectelick te leeren ofte te schrijven: Gelyck ook dat wij niet alleen alle dwalinghen, daer teghen strijdende, ende namentlick die inden voorss sijnodo gecondemneert zijn, verwerpen; maer oock zullen tegenstaen, wederleggen ende helpen weeren. Ende indien het zoude mogen gebeuren, dat wy na desen enich bedencken ofte ghevoelen tegen de voorss leere, ofte eenich poinct derselver zouden moghen crijgen, beloven wij, dat wy ' $t$ selve noch opentlick noch heymelick zullen voorstellen, dryven, predycken, ofte schryven; maer dat wy ' $t$ selve alvoren den kerckenraet, classi 
ende synodo zullen openbaren, om vande selve geëxamineert te worden; bereyt zynde het oordeel derselver altyt ghewillichlick ons te onderwerpen; op pene dat wij hyer teghen doende ipso facto van onsen dienst zullen zyn gesuspendeert. Ende indien ' $'$ enighen tyde de kerckenraet, classis, ofte sijnodus om ghewichighe oorsaecken van nadenken zouden moghen goet vinden, tot behoudinhe van de enicheyt ende suijverheyt inde leere, van ons te vereyschen onse naerder gevoelen ende verclainhe, zoo beloven wij oock midts desen dat wij daer toe allen tiden bereyt ende willich zyn zullen op pene als boven, behoudens t' recht van appèl in csu van beswaernisse, geduerende welcken tyt van appèl wij ons naer de uytspraeck ende ordre des sijnodi provincialis zullen reguleeren.

(Bouwman 1934:574-575)

Op die volgende belangrike aspekte moet die aandag gevestig word:

- Hier word plegtig verklaar dat die leer van die kerk, soos dit vervat is in die belydenisskrifte in alles met Gods Woord ooreenkom. Bowendien word die verklaring in opregtheid en met 'n skoon gewete voor God afgelê omdat die ondertekenaar dit “... van herten ghevoelen ende geloven ...”. Dit hou in dat die belydenis ook uitdrukking was van die lewende geloof van die ondertekenaar.

- Dit blyk baie duidelik dat die Skrif die norma normans is, die kenbron en reêl van die geloof, wat inhou dat die belydenisskrifte daaraan onderworpe is en daaraan getoets moet word.

- Verder word hier 'n belofte afgelê dat die leer van die kerk, soos vervat in die belydenisskrifte, deur die ondertekenaar geleer, bevorder en beskerm sal word. Dit spreek dan vanself dat hy self ook nie op enige wyse die leer onder verdenking sal plaas of sal ondergrawe nie, hetsy in die geheim of openlik, hetsy in woord of geskrif.

- Hier is egter nie sprake van gewetensdwang nie omdat hy die belofte vrywillig en van harte moes aflê. Terselfdertyd is ook verder aan die ondertekenaar die moontlikheid gegee om, indien hy 'n beswaar teen enige stuk van die leer sou ont- 
wikkel, die saak aan die oordeel van 'n bevoegde kerklike regeervergadering voor te lê vir beoordeling.

- Die ondertekening is duidelik gesien as uitdruklike erkenning van persoonlike instemming met die leer van die kerk en terselfdertyd 'n verklaring dat in eenheid met die kerk gelewe sal word.

- Indien die ondertekenaar te enige tyd ontrou word aan sy eie belofte en onderneming, is hy ipso facto gesuspendeer.

- $\quad$ Aan die ondertekenaar word ten slotte ook nog die versekering gegee van die reg tot appèl indien hy nie met die oordeel van ' $n$ mindere vergadering tevrede is nie.

Hoewel die ondertekeningsformule van Dordt tot in 1816 in die Nederlandse Hervormde Kerk die geldende formule gebly het, het die ondertekening van die formule teen die einde van die agtiende en begin van die negentiende eeu tot 'n baie groot mate betekenis verloor. Die toonaangewende figure in die kerk het hulle los van die geloof soos in die belydenisskrifte vervat, gevoel en het hulle slegs aan die Formuliere van eenheid gehou insoverre hulle eie oortuiging hulle toegelaat het (Bouwman 1934:575). Met die invoering in 1816 van ' $n$ totaal nuwe kerklike orde, wat geskoei was op die lees van die verenigingsreg, soos dit uit die Aufklärung na vore gekom het, is ook 'n nuwe ondertekeningsformule ingevoer (Pont 1991:79ev). Ten opsigte van die leer van die kerk, is van die ondertekenaar die volgende belofte gevra: “ ... dat wij de leer, welke overeenkomstig Gods Heilig woord, in de aangenomen formulieren van eenigheid der Nederkandse Hervormde kerk is vervat, ter goeder trouw aannemen en hartelijk gelooven, - dat wij dezelve naarstig zullen leeren en handhaven, ..." (Pont 1991:52).

Die woord "overeenkomstig" het vaagheid en verwarring gebring omdat dit nou nie meer duidelik was of die kandidaat die leer in die formuliere vervat glo omdat (= quia) of insoverre (= quatenus) dit met die Woord van God ooreenkom nie. Ook het die woord "aangenomen" nie beteken dat dit om aldrie die formuliere gegaan het nie, maar slegs om twee naamlik die Nederlandse Geloofsbelydenis en die Heidelbergse Kategismus. Omdat die Dordtse Leerreêls nie deur al die provinsiale sinodes van die Nederlande aanvaar is nie, is dit beskou as uitgesluit. Dié toedrag van sake kon nie anders as om onrus in die Nederlandse kerk te veroorsaak nie. Van die behoudendes het 
die aandrang gekom om terug te keer na die formule van Dordt. Diegene wat leervryheid in die kerk wou invoer het egter die oorhand in die sinode gehad, met die gevolg dat in 1854 'n quatenus standpunt uitdruklik aanvaar is toe die formule verander is om te lui: “... dat wij des zins en willens zijn den geest en de hoofdzaak der leer, welke in de aangenomen formulieren van eenigheid der Nederlandse Hervormde Kerk begrepen is, getrouw te handhaven". "Geest en Hoofdzaak der leer" is dan verstaan as "... dat gene, wat leeft in het gemoedelijk bewustzijn, of liever in de gemoedelijke overtuiging van de grote meerderheid dier Leden, voor welke de godsdienst, in meerder of mindere mate, zaak des harten is" (Pont 1991:99). Uiteindelik is in 1888 'n formule ingevoer wat gladnie meer die belydenisskrifte genoem het nie. Die verwatering van die ondertekeningsformule het tot gevolge gehad dat die Nederlandse Hervormde Kerk 'n modaliteitekerk geword het waarin daar plek was vir elke teologiese opvatting en rigting vanaf vrysinnig-liberaal tot ultra-ortodoks.

\section{Literatuurverwysings}

Augustyn, C 1970. Kerk en belijdenis. Kampen: J H Kok.

Bouwman, H 1934. Gereformeerd Kerkrecht, Deel 2. Kampen: J H Kok.

Dankbaar, W F 1957. Calvijn zijn weg en werk. Nijkerk:Callenbach.

De Wet, J I 1973. Is 'n nuwe belydenis moontlik en nodig? In die Jaarblad van die Van der Hoff Teologiese Vereniging.

Haitjema, Th L 1951. Nederlands Hervormd Kerkreg. Nijkerk: G F Callenbach.

Hesselink, I J 1997. Calvin's first Catechism: A commentary. Louisville, KT: Westminister John Knox Press.

Parker, T H L 1975. John Calvin. London: Dent \& Sons.

Plomp, J 1969. De kerkelijke tucht bij Calvyn. Kampen: J H Kok.

Pont, A D 1981. Die historiese agtergronde van ons kerklike reg, Deel 1, Pretoria: Kital.

- 1982. Die belydenis in historiese verband in HTS 38 (2\&3), 1-29.

- 1991. Die historiese agtergronde van ons kerklike reg, Deel 2, Pretoria: Kital.

- 1994. 'n Inleiding tot die Nederlandse Kerkgeskiedenis:van die beginjare tot 1795. Pretoria: Universiteit van Pretoria: (HTS Suppl 6). 
Praamsma, L sj. De belijdenis in de krisis, Wageningen:N V Gebr Zomer \& Keunings Uitgeversmaatschappij Reitsma, en Lindeboom.

Smith, P M 1982. Brief in sake memorandum proponentsformule. Pretoria: NHKA.

Vorster, J D 1956. Die kerkregtelike ontwikkeling van die Kaapse Kerk onder die Kompanjie 1652-1792, Potchefstroom: Pro Rege.

Kleynhans, E P J 1974. Die kerkregtelike ontwikkeling van die Nederduitse Gereformeerde Kerk in Suid-Afrika 1795-1962, DD-proefskrif, Universiteit van Stellenbosch. 